Jolanta Sztachelska

Wydział Filologiczny

Uniwersytet w Białymstoku

e-mail: jsztachelska@wp.eu

\title{
Wobec Zoli
}

Francuskie wydanie Quo vadis z 1983 roku (Ed. Flammarion) zaczyna się przedmową, która od pierwszego zdania przyprawia mnie o konfuzję. Autor tego wstępu, Daniel Beauvois, konstatuje: „Henryk Sienkiewicz napisał Quo vadis przeciwko Zoli" ${ }^{1}$.

Oczyma wyobraźni widzę zastępy sienkiewiczologów, którzy jak husaria za króla Jana III napierają, by co rychlej tezę tę udowodnić... Zastanawia mnie, skąd Daniel Beauvois czerpie swoje przekonanie? Czyżby wczytał się tak głęboko w Sienkiewicza, że przejrzał go na wylot, albo wie coś, czego inni przed nim nie dostrzegli? Ma nowe dowody? Bynajmniej. A zatem skąd więc ów interpretacyjny przełom? Czyżby od Wacława Nałkowskiego? W 1904 roku wychodzi zbiór słynnych paszkwili tego publicysty pod tytułem Sienkiewicziana $^{2}$, stanowiący ostatni akord nagonki, jaką młode pokolenie twórców, skupione wokół warszawskiego "Głosu”, w tym najwybitniejszy z nich Stanisław Brzozowski, zgotowało niedawnemu jubilatowi (1900), światowej sławy pisarzowi i autorytetowi numer jeden polskiej literatury końca XIX i początków XX wieku. W zbiorze tym publicysta w sposób bezpardonowy

\footnotetext{
* Projekt został sfinansowany ze środków NCN przyznanych na podstawie decyzji DEC2012/06/A/HS2/00252.

1 H. Sienkiewicz, Quo vadis, introduction, glossaire chronologie et bibliographie de Daniel Beauvois, trad. d'Ely Halpérin-Kaminski, GF Flammarion Paris 1983, p. 5.

2 W. Nałkowski, Sienkiewicziana: szkice do obrazu, Kraków 1904.
} 
chłoszcze autora Trylogii przeciwstawiając mu Zolę, autorytet i wzór młodego, lewicującego pokolenia, które w autorze Bestii ludzkiej i Germinal dostrzegło to coś, czego u siebie, na gruncie polskim znaleźć nie umiało. W obszernym zbiorze szkiców opluwających Sienkiewicza na wszystkie możliwe sposoby, w których określenie „ideolog burżujów” jest bodaj najłagodniejszym, Nałkowski zamieścił niewielki rozdział poświęcony Zoli, dowodząc w nim z całym przekonaniem, że nie ma ludzi bardziej sobie obcych, niż "grubiański” Zola, który „zdziera maski z wszelkiego fałszu i hipokryzji”, i „idealny Pan Sienkiewicz", któremu ludzie pokroju Zoli odbierają zdrowy sen i przeszkadzają w "spokojnym artystycznym trawieniu”. Ponieważ poziom tych argumentów, albo może trafniej - inwektyw - nie wydaje się przesadnie wysoki, na tym cytacje z Nałkowskiego zakończę. Podkreślę jedynie, że „przykładanie” Sienkiewiczowi Zolą za pomocą retoryki zaczerpniętej $\mathrm{z}$ „"kampanii antysienkiewiczowskiej" ma wyjątkowo długą tradycję w naszej krytyce i utrzymało się także w okresie powojennym. Nie jest zresztą tajemnicą, że została ona uformowana przez wrażliwość lewicową, a Brzozowski pełnił w niej rolę swoistego katalizatora i autorytetu - od lewej do prawej strony, od przedwojennego marksisty Andrzeja Stawara po subtelnego personalistę Kijowskiego ${ }^{3}$. Czy się to nam podoba, czy nie, krytyka polska kroczyła tą samą ścieżką, która została jej wytyczona na początku XX wieku.

Otwieram książkę z lat 70. XX wieku na temat inspiracji naturalistycznych w polskiej literaturze II połowy XIX i początków XX wieku pióra zasłużonej dla badań nad pozytywizmem Janiny Kulczyckiej-Saloni ${ }^{4}$. Porównaniu Sienkiewicz-Zola poświęca się tu duże fragmenty i, podobnie jak Daniel Beauvois, autorka nie ma wątpliwości: „Sienkiewicz był pisarzem, który całkowicie, bez zastrzeżeń odrzucił Zolowską koncepcję literatury". Badaczka twierdzi także, że właściwie nie dał nic konkretnego w zamian, poza rzuceniem myśli o „wspinaniu się wzwyż" 5 .

Sięgnięcie po tę klasyczną książkę ma swoje głębokie uzasadnienie. Kulczycka-Saloni przypomina bowiem, kto rozpoczął na gruncie polskim to przeciwstawianie obu prozaików. Jej zdaniem pierwsza zrobiła to w 1885 roku Stefania Chłędowska ${ }^{6}$, która oparłszy swój sąd na porównaniu sceny mszy u obu pisarzy, wprowadziła w obieg przekonanie, że Zola, zwolen-

\footnotetext{
3 Piszę o tym w artykule $W$ meandrach PRL-owskiej krytyki. Sienkiewicz między Stawarem a Kijowskim, w: Mity sienkiewiczowskie, Warszawa 2016 (książka w druku).

4 J. Kulczycka-Saloni, Literatura polska lat 1876-1902 a inspiracja Emila Zoli. Studia, Wrocław 1974.

5 Tamże, s, 177.

6 S. Chłędowska, Szkice literackie, Warszawa-Lwów 1885, t. 1, s. 134.
} 
nik deskrypcji behawioralnej, to zdeklarowany ateusz, a Sienkiewicz - koncentrujący się na pokazaniu, jakie wrażenie zrobiło nabożeństwo na stroskanej duszy biednej kobiety - fideista. „To przeciwstawienie - konstatuje badaczka - okazało się wyjątkowo trwałe". Dlaczego? Kulczycka pisze: „literatura polska miała swego Sienkiewicza z jego patriotycznymi i religijnymi ideałami, natomiast nie miała jego antytezy"7. Właśnie to przeciwstawienie - czytamy dalej - zapoczątkowane przez krytyków niechętnych pozytywistyczno-scjentystycznym tendencjom epoki, „zostało w pełni wyeksploatowane przez przedstawicieli intelektualnej lewicy", którzy znajdowali w nim wyjątkowe upodobanie ${ }^{8}$. Do paradoksu ściśle polskiego należy zaliczyć i to, że również prawica chętnie wykorzystywała ten gotowy schemat. Pokusa łatwej schematyzacji nasilała się zatem nie tylko bez udziału zainteresowanego (Sienkiewicza), jak też całkowicie poza jego wiedzą. "Siła fatalna” efektownego zestawienia i mechanizm braku reakcji ze strony pisarza, to jego słynne sans le savoir ${ }^{9}$, dopełniły interpretacyjnej tradycji.

\section{Francuskie podróże i korespondencje}

Jest niemal banałem przypomnienie, że dla pisarzy polskich XIX wieku kultura francuska oznaczała najwyższy europejski standard, a głośne nazwiska jej twórców, mimo konkurencji, jaką stała się w II połowie wieku literatura angielska, a nawet amerykańska, długo jeszcze stanowiły niezbędny układ odniesień i porównań. Francuskiego uczył się Sienkiewicz w gimnazjum i na studiach, naturalne były zatem jego zainteresowania literaturą francuską. Do Francji pojechał po raz pierwszy w 1874 roku, przez około dwa tygodnie mieszkał w Paryżu u przyjaciela Daniela Zglińskiego. Kompletnej relacji z tego pobytu nie mamy, poza prywatnymi listami do Marii Kellerówny, w których donosi: „Paryż przepychem, ogromem, szaloną wesołością, oryginalnym charakterem i ciekawościami przeszedł wszelkie moje oczekiwania"10. Następny przyjazd do Paryża nastąpił w 1878 roku (pisarz jest tam od początków kwietnia), w drodze powrotnej z Ameryki. Sienkiewicz

\footnotetext{
7 J. Kulczycka-Saloni, Literatura polska lat 1876-1902..., s. 178.

8 Zob. G. Glass, Wizerunek człowieka poczciwego w r. 1906 w Polsce poczciwego, Kraków 1908.

9 Zasadę nieingerencji w recepcję swoich utworów jako strategię pisarską Sienkiewicza po raz pierwszy opisuje Andrzej Stawar w eseju Sienkiewicz, drukowanym w "Kuźnicy” w 1946 roku. Zob. mój tekst: Sienkiewicz w meandrach PRL-owskiej krytyki...

10 H. Sienkiewicz, Listy, red. J. Krzyżanowski, oprac. M. Bokszczanin, konsult. M. Korniłowicz, t. 3, cz. 1, Warszawa 2007, s. 113 (list z 22 września 1874).
} 
decyduje się wtedy na pozostanie we Francji z wielu powodów. Po pierwsze czeka na nowy paszport, który utracił ważność, po drugie zwleka ze względu na nieustabilizowaną sytuację polityczną. W Europie od 1876 roku mówi się o nowej wojnie, na Bałkanach wybucha konflikt zbrojny pomiędzy Rosją i Turcją, który wkrótce zmieni geopolityczną mapę kontynentu. Jako poddany rosyjski Sienkiewicz obawia się powołania do wojska.

O czasie spędzonym w Paryżu wiemy i dużo, i bardzo mało. W ciągu rocznego pobytu we Francji pisarz robił wypady do Grandcamp (sierpień 1878), gdzie spotkał się z Adamem Asnykiem oraz wyjeżdżał na Huculszczyznę i do Galicji (Lwów, Szczawnica, Krynica), by po pierwsze - zarobić na swoje utrzymanie odczytami na tematy amerykańskie, po drugie - wypromować wystawiany na scenie lwowskiej dramat (marzec 1879) oraz dopilnować innych publikacji. Co jednak naprawdę robił w Paryżu, z kim się spotykał - tu wiemy stosunkowo mało. Jeden trop - to artyści, przebywający wówczas w Paryżu, z którymi przemieszkiwał, m.in. Antoni Piotrowski ${ }^{11}$, który odegra specyficzną rolę w wątku bałkańskim, aluzyjnie pojawiającym się w korespondencji Sienkiewicza z Wenecji (wrzesień 1879). Drugi trop - to Bruno Abakanowicz, przyjaciel pisarza, który prawdopodobnie już od 1878 roku okresowo przebywał nad Sekwaną, szukając kontaktów i możliwości rozwoju swoich naukowych zainteresowań. W 1878 roku "Nowiny” warszawskie publikują opis przejażdżki balonem Giffarda w ogrodach Tuileries pióra Abakanowicza. To ten sam balon, do którego w Paryżu wsiadają Geist i Wokulski, ten sam, z którego bohater powieści Prusa ujrzał na niebie czarne słońce melancholii.

Okres paryski, jak utrzymuje Tadeusz Bujnicki, ma wielkie znaczenie $\mathrm{w}$ rozwoju twórczości Sienkiewicza ${ }^{12}$. Powstały wtedy, poza Listami z Paryża, których tematem jest głównie odbywająca się w 1878 roku wystawa światowa, dwa sprawozdania: z Międzynarodowego Kongresu Pisarzy oraz wystawy antropologicznej oraz wiele utworów literackich, przy czym są to rzeczy tak różne, jak Przez stepy oraz Jamioł czy Janko Muzykant. Korespondencje paryskie to bez wątpienia dowód bardzo radykalnej postawy światopoglądowej pisarza. Ta radykalizacja dokonała się podczas niemal trzyletniego pobytu w Ameryce. Przemyśleniu pewnych kwestii, dotyczących porównania

11 Antoni Piotrowski był korespondentem pism angielskich i francuskich, m.in. „Le Monde Illustré", „Illustration”, „The London Illustrated News”, ,The Graphic” z tzw. wojny wschodniej. W Bułgarii był w roku 1879, 1885 i 1889. Brał udział jako ochotnik w wojnie serbsko-bułgarskiej w 1886 roku. Pozostawił po sobie Autobiografię.

12 T. Bujnicki, Sienkiewicz przekracza granice. O „przełomie” w życiu i twórczości pisarza, w: tegoż, Sześć szkiców o Zagłobie i inne studia sienkiewiczowskie, Warszawa 2014, s. 111. 
cywilizacji europejskiej i amerykańskiej, różnych typów modernizmu (w krajach Zachodu i w Privislinskim Kraju ${ }^{13}$, sferze silnych wpływów rosyjskich ${ }^{14}$ ), a także postaw patriotycznych Polaków, sprzyjało oddalenie i atmosfera wolności. We Francji następuje intensyfikacja tych procesów. Widać to niemal na każdym kroku i w każdym pisanym nad Sekwaną tekście. Reporter krytycznie spogląda na wielkie targowisko próżności, które się odbywa przy okazji otwarcia wystawy. Nie porywa go ani rozmach przedsięwzięcia, ani przepych ceremonii, nawiedzają natomiast gorzkie refleksje dotyczące różnic cywilizacyjnych Nowego i Starego świata. Przypatrując się wielkim postaciom ówczesnej polityki, nie szczędzi im złośliwości, widząc w nich głównie skarlałe charaktery, wielkie ambicje i przerośnięte ego. Francuski model demokracji, oparty głównie na retoryce i teorii, przegrywa $\mathrm{w}$ jego mniemaniu $\mathrm{z}$ amerykańskim, gdzie demokrację po prostu się stosuje. Triumf wystawy paryskiej potwierdza jednak, jego zdaniem, dobry kierunek rozwoju republiki. Ocena Francji jako modelu ustrojowego nie jest jednak łatwa, to trochę jak Paryż: „niedokończona uczta z czasów ostatniego Nerona” ${ }^{15}$. Ale - pisarz jest tego pewien - po długiej nocy przyjdzie świt. O przyszłości nie będą jednak decydować mieszkańcy pięknych bulwarów, ale ci, którzy żyją na przedmieściach:

Tam śpi przyszła rzeczypospolita, aby nazajutrz ze świeżymi siłami rozpocząć pracę odrodzenia; pójdźcie na Pole Marsa, a zamiast odgłosów orgii usłyszycie dniem i nocą dźwięczenie młotów, turkot wozów, świst lokomotyw - tam pracuje demokracja francuska ${ }^{16}$.

Sienkiewicz-radykał powiada:

Jeśli jest jakaś nadzieja dla Francji na przyszłość - jak się teraz zdaje, że jest to leży ona naprawdę w demokracji, w tych klasach, które do życia politycznego nie były jeszcze powołane. Inne klasy są stare zepsute, przeżyte i sceptyczne. Nie służą ideom, ale osobom ${ }^{17}$.

13 Względy cenzuralne nie pozwalały w zaborze rosyjskim na posługiwanie się nazwą Polska, stąd rosyjskie: Privislinskij Kraj.

14 Kwestie dwóch modernizmów (zachodnioeuropejskiego i rosyjskiego, na osi Paryż-Petersburg) oświetla w duchu Bermanowskiej analizy (M. Berman, „Wszystko co stałe rozplywa się w powietrzu". Rzecz o doświadczeniu nowoczesności, przeł. M. Szuster, wstęp A. Bielik-Robson, Kraków 2006) Filip Mazurkiewicz, interpretując opowiadanie Bolesława Prusa Milknące głosy. Zob. F. Mazurkiewicz, Opowieści nowoczesne, Katowice 2015, s. 7-35.

15 H. Sienkiewicz, Listy Litwosa z Wystawy Paryskiej, w: tegoż, Dzieła, red. J. Krzyżanowski, t. 44: Listy z podróży $i$ wycieczek, Warszawa 1950, s. 50.

16 Tamże, s. 50.

17 Tamże. 
Tym bezpardonowym stwierdzeniom towarzyszą też opinie dotyczące kultury.

Możemy się tylko domyślać, jak wiele zyskał Sienkiewicz podczas tego roku w Paryżu. W korespondencjach nie tylko wykazuje się znajomością sztuk pięknych - zna najnowsze tendencje $\mathrm{w}$ malarstwie, ale pisze także o błyskotliwej karierze Sary Bernhardt, przysłuchuje się międzynarodowemu kongresowi pisarzy, którzy debatują o własności intelektualnej, rozpoznaje najnowsze utwory Taine'a, Renana i ich polityczne konotacje, uczęszcza na wykłady w Collège de France, potrafi scharakteryzować intelektualny potencjał kultury francuskiej i nie są to ogólniki. W umysłowym życiu francuskim ceni nade wszystko: inicjatywę $w$ idei i czynie oraz uniwersalizm problemów społecznych, objawiających się z większą niż gdzie indziej dobitnością ${ }^{18}$, w pisarzach, których pilnie wtedy czyta (wśród nich powtarzają się nazwiska Balzac, Hugo, Stendhal, Flaubert, Daudet, Zola), postrzega ludzi „życia, walki i czynu"19. W korespondencji paryskiej z $1879^{20}$ roku, wyraźnie pod wpływem wykładów Paula Alberta (profesora Collège de France) na temat najnowszej literatury francuskiej, szuka odpowiedzi, w jakim kierunku idzie we Francji współczesnej sztuka słowa. Różnica pomiędzy jej kulturą a innymi narodami Europy kryje się, jego zdaniem, w tradycji klasycyzmu francuskiego, hamującego w swoim czasie rozwój idei romantycznych. Romantyzm francuski, pozbawiony tych elementów, które stały się zasadniczym rysem np. literatury polskiej, tj. wpływu twórczości ludowej oraz idei narodowej, nie miał charakteru wypływającego z jego duchowości. Zawierał pierwiastki postępu, bo postawił na indywidualizm, „rozkuł poezję z kajdan przepisów" i wprowadził nowe treści nawiązujące do średniowiecza, ale w kraju, który w wieku XVIII przeżył głęboką rewolucję socjalną, szybko popadł w anachronizm i dziwactwo. Nic więc dziwnego, że reakcja, która po nim nastąpiła, była tak radykalna. Jest nią - pisze Sienkiewicz - naturalizm, czyli - „zwrot do zwyczajnego, codziennego życia, do realnych charakterów i do rzeczywistych stosunków" ${ }^{21}$. Szkoła naturalizmu francuskiego - jak objaśnia pisarz - jest czymś w rodzaju maniery flamandzkiej w malarstwie. Chodzi o to, by malować wiernie, chwytać życie na gorącym uczynku. Ponieważ koncentracja na tych kwestiach wydawała się najważniejsza, fantazję oddano pod straż prawdopodobieństwa, a „bajka” (czyli

\footnotetext{
18 H. Sienkiewicz, Listy Litwosa z Paryża. Salon z roku 1878, w: tegoż, Dzieła, t. 44, s. 82-84.

19 Tamże, s. 83.

20 H. Sienkiewicz, Z Paryża przez Litwosa, "Gazeta Polska”, 20-23 stycznia 1879 , nr 14-17, przedruk: Dzieła, t. 44 , s. $138-157$.

21 H. Sienkiewicz, tamże, s. 152.
} 
$\mathrm{w}$ terminach Sienkiewiczowskich - fabuła) wraz z sensem moralnym zeszły na dalszy plan. Najwybitniejsi reprezentanci tego kierunku, mającego swoje antecedencje w twórczości Balzaca i Stendhala, to, według Sienkiewicza, Zola i Daudet. Czy naturalizm to ostanie słowo literatury? W tej chwili trudno na to odpowiedzieć, Sienkiewicz jest jednak optymistą: „Dla powieści naturalizm był $\mathrm{w}$ zasadzie znakomitym, niezbędnym i może jedynym krokiem naprzód" 22 .

\section{Korespondencje i prowokacje}

Zatrzymałam się na korespondencjach paryskich z 1878 i 1879 roku, ponieważ nie wydaje mi się, by poglądy Sienkiewicza uległy w ciągu roku czy dwóch jakiejś diametralnej zmianie. A tak, tradycyjnie, się to ujmuje. Nie ustrzegł się takiej opinii również Tadeusz Bujnicki, który, po omówieniu radykalnej postawy pisarza i skomentowaniu pozytywnej oceny naturalizmu, stwierdza: „Co ciekawe, ta ocena jest wyraźnie odmienna od tej, którą pisarz sformułował dwa lata później w warszawskich odczytach o naturalizmie" ${ }^{23}$. Przede wszystkim chcę zwrócić uwagę na chronologię. Cytowana korespondencja z Paryża była drukowana w styczniu 1879 roku, na jesieni tego samego roku Sienkiewicz jedzie do Italii i pisze stamtąd dwie korespondencje - z Wenecji i z Rzymu. Zwłaszcza ta pierwsza jest ciekawa, bo Sienkiewicz, ujawniając istnienie dwóch Wenecji - folderowej, dla turystów i tej z zaplecza - ludowej, ani na chwilę nie przestał być tym Sienkiewiczem, którego znamy z Paryża. W listopadzie pisarz jest już w Warszawie i w tym samym miesiącu, przynaglony koniecznością życiową i - prawdopodobnie - nową miłością, którą spotkał na swojej drodze ${ }^{24}$, rozpoczyna współpracę z pismami warszawskimi. W "Gazecie Polskiej” pisze Wiadomości bieżące, od grudnia w dwutygodniku „Niwa” ukazują się Mieszaniny literacko-artystyczne, w których w swobodnej formie recenzuje nowości wydawnicze, wydarzenia teatralne, wystawy malarskie. Grudniowy, pierwszy odcinek Mieszanin zaczyna się małym skandalem. Sienkiewicz zjadliwie komentuje konserwatywną linię pisma, które wyraźnie zeszło z dotychczasowej

\footnotetext{
22 Tamże, s. 153.

23 T. Bujnicki, Sienkiewicz przekracza granice, s. 112.

24 Prawdopodobnie w Szczawnicy, gdzie był z odczytem, poznał rodzinę Szetkiewiczów i swoją przyszłą żonę, Marię. Za nimi udał się do Italii, skąd nadsyłał korespondencje. Zob. Z Wenecji przez Litwosa, prwdr. "Gazeta Polska” 25-26 sierpnia 1879, nr 214-215; "Gazeta Lwowska” 24-26 września 1879, nr 224-226; List z Rzymu przez Litwosa, prwdr. "Gazeta Polska” 18 października 1879, nr 234.
} 
drogi ${ }^{25}$ i określa swoją nową rolę, nie wykazując przy tym najmniejszego entuzjazmu. Pisze aluzyjnie, posługując się szekspirowską przesłoną: „Nie mam żadnych powodów do dobrego humoru; jestem raczej jak ów Tomek z Króla Leara, bo zimno mi pod każdym względem" ${ }^{26}$. W tym samym odcinku znajdujemy omówienie komedii Asnyka Przyjaciele Hioba i niezbyt udanej powieści Grudzińskiego. Oba te utwory skłaniają komentatora do stwierdzenia, że w dzisiejszej literaturze nade wszystko brakuje oryginalnych charakterów. By wzmocnić swoje argumenty Sienkiewicz posługuje się szerszą perspektywą, przykładem literatury europejskiej:

to się tłumaczy nowym kierunkiem, a raczej jego skrajnością. Powieść zwróciwszy się do rzeczywistości stała się ostrożniejszą $\mathrm{w}$ tworzeniu postaci posągowych niż rzeczywistość sama. Tak się stało we Francji - i u nas. We Francji brak nie tylko ludzi $\mathrm{w}$ powieściach, ale nawet $\mathrm{i}$ idei ${ }^{27}$.

Wytknąwszy naturalizmowi obniżenie lotów w zakresie tworzenia postaci, Sienkiewicz wskazuje odstępstwo od tej zasady, omawiając powieść Daudeta Le roi en exil ${ }^{28}$. Jak widać, tylko w ciągu tego samego roku 1879 aluzje do powieści francuskiej i naturalizmu pojawiają się częściej, niż byśmy się spodziewali. Można by powiedzieć tak: Sienkiewicz pełną garścią czerpie z doświadczeń pobytu w Paryżu. Nie ostygnie również w roku następnym. W VIII odcinku Mieszanin, które wychodzą w 1880 roku (w lipcu), a więc kilka miesięcy przed grudniowymi odczytami O naturalizmie, Sienkiewicz pisze recenzję powieści Edmunda Abouta Le roman d'un brave homme. Recenzja nosi znamienny tytuł Przeciw Zoli.

\section{Chacun selon son gôut}

Powieść Abouta, zagorzałego antyklerykała i republikanina, pochodzi z 1880 roku, jest więc absolutną nowinką. Sienkiewicz ujawnia, że zanim się ukazała, już głośno było we Francji, że autor chce się zmierzyć z Zolą,

25 Po wyznaniu, że nie będzie kronikarzem jak inni, Sienkiewicz pisze, że nie mógłby przyjąć takiej posady w „Niwie”, bo jest zajęta, ale także: „Nie zdaje mi się, aby wóz społeczny leciał u nas tak na złamanie karku po pochyłości radykalizmu, żeby aż trzeba było dyrdać za nim i krzycząc: tprrru! podkładać pod koła dokumenta wymagane tylko u Kanoniczek [...]". Redakcja "Niwy” wyznania Sienkiewicza opatrzyła komentarzem, iż będąc w podróży Sienkiewicz wyrobił sobie błędne wyobrażenia na temat pisma. Zob. H. Sienkiewicz, Mieszaniny literacko-artystyczne (I), w: tegoż, Dzieła, t. 50, s. 3.

\footnotetext{
26 Tamże, s. 4.

27 Tamże, s. 13.

28 Tamże, s. 14.
} 
tworząc coś absolutnie mu przeciwstawnego. Recenzent Mieszanin poświęca mu zatem więcej uwagi, niż innym produkcjom literackim. Rzeczywiście, po obszernym streszczeniu utworu opowiadającego o dolach i niedolach pewnej mieszczańskiej rodziny, widzimy, że autor postanowił sprzeciwić się skrajnościom naturalizmu. Swoje osiągnął, pisze Sienkiewicz: „Niech będzie dwóch: Zola do malowania czarno i About do malowania biało. Chacun selon son gôut! Można utrzymywać, że w literaturze, tak jak i w przyrodzie, winna panować rozmaitość" 29. Ale cóż z tego? Powiada Sienkiewicz: About, "porządny literat" w każdym calu ${ }^{30}$, Zoli jednak nie dorównuje. Jego powieść jest zwyczajnie nudna, brak jej tego czegoś, co tworzy wielką literaturę. I tu następuje kapitalny fragment, w którym recenzent zderza dwa portrety. Warto je przypomnieć, bo pokazują polemiczny talent Sienkiewicza:

Gdy sobie przypomnę twarz Abouta, zażywną, okrągłą, rumianą, o czarnych oczach błyszczących dowcipem - twarz porządnego burgeois, i zestawię ją z obliczem Zoli, z którego, jak i z jego utworów, przebija jakaś siła brutalna a chłodna, nie mogę oprzeć się myśli, że About przegra powieściową wojnę z Zolą ${ }^{31}$.

Recenzent na jednego i drugiego patrzy krytycznie, ale nie ma też wątpliwości, że w kwestiach artyzmu konkurent autora Nany nie ma absolutnie nic do powiedzenia. Sienkiewicz przy tym wszystkim nie zmienia swego sądu, $\mathrm{w}$ dalszym ciągu utrzymuje, że naturalizmowi brakuje wielkich idei. Zoli nie obali jednak - pisze wnikliwie - „idealizowanie życia małomieszczańskiego, które $\mathrm{w}$ rzeczywistości jest płaskim i przepełnionym groszowym oportunizmem”. Może to zrobić tylko ktoś, kto potrafi „uderzyć w dzwon wielkich idei. Wówczas i umysły ludzkie równie wielkim ruchem się rozkołyszą i o wszystkim, co się do nowej miary nie dostosuje - zapomną..." ${ }^{32}$.

\section{Odczyt warszawski}

Na tym tle widziany odczyt Sienkiewicza $O$ naturalizmie, wygłoszony 2 i 9 grudnia $1880^{33}$, interpretowany powszechnie jako zdecydowany opór wobec nowego kierunku literackiego i jego głównego prawodawcy - Emila

\footnotetext{
${ }^{29}$ H. Sienkiewicz, Przeciw Zoli (E. About, Le roman d'un brave homme), w: tegoż, Mieszaniny literacko-artystyczne (VIII), s. 87.

30 Tamże, s. 89.

31 Tamże.

32 Tamże, s. 90.

33 Drukowane w „Niwie” 1881, t. 2.
} 
Zoli, nie jest już ani specjalnie odkrywczy, ani też tak radykalny, jak się to od wieków utrzymuje. Zdecydowana większość poglądów, które się tam znalazły, to powtórzenie tego, co już wcześniej pisarz głosił. Znacznie bogatsza jest w tym utworze natomiast strona egzemplifikacyjna, którą się Sienkiewicz posługuje, oraz tło historyczno-literackie, wprowadzające $\mathrm{w}$ tajniki przemiany prądów literackich, które według niego raz wychylają się w stronę ideału, to wracają znów w stronę prawdy. W odczycie ciągle brzmią echa wysłuchanych w Paryżu wykładów. Sienkiewicz przedstawia się tutaj jako zwolennik realizmu, który rozumie jako konieczność wynikającą z reakcji przeciwko romantyzmowi. Zwłaszcza dla powieści - podkreśla - realizm otwiera „widnokrąg tak szeroki jakim jest byt ludzki" ${ }^{34}$. Realiście zawsze i niezmiennie idzie o takie pokazywanie rzeczywistości, która może być piękna, szpetna, pociągająca, ohydna, ale jest rzeczywistością i prawdą ${ }^{35}$. Ale, dodaje - po wzlotach romantyzmu realizm musi wydawać się rezygnacją, widać to także $\mathrm{w}$ filozofii pozytywnej, która wyrzekła się metafizyki ${ }^{36}$.

Sienkiewicz przypomina, że o naturalizmie, z którym realizm często jest mylony, mówi się przede wszystkim w atmosferze plotki i skandalu. W pewnym sensie stał się on "synonimem literatury rozpętanej, szalonej, jaskrawej, mającej za cel główny opisywanie brudów ludzkiego życia i jego obrzydliwości" ${ }^{37}$. Gdyby jednak - powiada Sienkiewicz - chodziło tylko o szarganie tradycyjnej moralności czy naruszanie norm, sprawa trafiłaby do sądu i mogłaby być ścigana przez policję. Ale tu nie o to przecież idzie. Więc o co? Dopowiedzmy za autora odczytu: jest w nim pewna koncepcja człowieka i życia. Czy zasługująca na to, aby o niej mówić? Czy naturalizm, zastanawia się prelegent, dał powieści coś więcej nad to, co ofiarował jej realizm?

Według Zoli człowiek to suma składników; jest tu komponent fizjologiczny, historyczny i socjalny. Nietrudno dostrzec w tym wpływ teorii Taine'a, którego Zola był wiernym i pilnym uczniem. Tyle że to, co wydaje się wielką zdobyczą Zoli, pisze Sienkiewicz, istniało długo przed nim - w twórczości Balzaca, Stendhala, Flauberta, Champfleury'ego. Na tle ich twórczości autor Nany okazuje się jednostronny i niewolniczo przywiązany do swych teorii. Widać to nader jasno w uproszczonej psychologii człowieka, sprowadzonej właściwie do fizjologii, negującej istnienie takiego składnika w rozwoju duchowości ludzkiej, jak kultura. U Balzaka, przypomina Sienkiewicz,

\footnotetext{
34 H. Sienkiewicz, O naturalizmie, w: tegoż, Dzieła, t. 45: Szkice literackie, cz. 1, Warszawa 1951, s. 62 .

35 Tamże, s. 63.

36 Tamże, s 64.

37 Tamże, s. 59.
} 
człowiek działa pod wpływem uczuć i wrażeń, u Zoli jest tylko odziedziczonym po przodkach temperamentem, ukształtowanym pod wpływem warunków socjalnych ${ }^{38}$. Nic zatem dziwnego, że prezentowana w jego utworach wizja życia jest głęboko pesymistyczna - to wizja totalnego zepsucia, niskich instynktów i pożądliwości ${ }^{39}$. Sienkiewicz rozumie, że kryje się w tym obrazie pisarska aksjologia, Zolowska diagnoza stanu społeczeństwa francuskiego za II Cesarstwa, ale przecież, dodaje - to nie jest cała prawda o życiu Francuzów! Zola, kreśląc taką wizję, nie osiąga zamierzonego rezultatu - prawdy. Wszędzie tam, gdzie podporządkowuje się teorii naukowej, przestaje być artystą, staje się zaś doktrynerem, fanatykiem teorii dziedziczności. Sztuka podkreśla Sienkiewicz - nie może podporządkowywać się nauce, bo wtedy przestaje być sztuką. "Fantazja i fizjologia to contradictio in adiecto [...]" ${ }^{40}$. Zola, stojąc na stanowisku przedmiotowości i wypierając się szerzenia defetyzmu, sprzeniewierza się zadaniu artysty. Czytanie jego powieści zagraża duszy czytelników - grozi jej moralna anemia, traci ona zdolność odczuwania piękna, polot, obniża się. $Z$ drugiej strony, Zola nie raz wykazał, że potrafi być ponad doktryną. Sienkiewicz ma tu na myśli takie jego postacie, jak Silver, Mietta, dr Pascal, Florian, Allina i jej dziadek - wyjątki w galerii łotrów. Podoba mu się także opowiadanie Atak na młyn (z Wieczorów medańskich), pozbawione naturalistycznych przejaskrawień, dowodzące potęgi talentu autora. Właściwie nie ma wątpliwości, że Zola to ktoś wyjątkowy, obdarzony niezwykłym powieściopisarskim instynktem, prawdziwy Holender w odtwarzaniu współczesności, któremu wyraźnie ciasno w klatce naturalistycznej teorii.

Kreśląc szeroko wizerunek najsłynniejszego francuskiego pisarza lat 80., komentowanego i drukowanego na całym świecie, Sienkiewicz zdaje sobie sprawę z wpływu, jaki wywarł on na sztukę europejską. Dla polskiego czytelnika nie mógłby jednak stanowić duchowego wzoru. Dlaczego? Zola jest nade wszystko produktem swojej kultury - twierdzi Sienkiewicz. Kultury wyrafinowanej i pozbawionej wyższych celów - to ocena stanu społeczeństwa francuskiego, pogrążonego $\mathrm{w}$ ideowym marazmie i konsumowaniu osiągniętego poziomu rozwoju. Pesymizm jest tu symptomem wyczerpania

\footnotetext{
38 Tamże, s. 84.

39 „Zbierając w całym cyklu Rougonów - z pominięciem wszelkiej proporcji naturalnej przeważnie cienie, brudy i zbrodnie, niskie popędy, posępne następstwa zboczeń mózgowych, pijaństwa i podając ów zbiór jako naturalny obraz życia, Zola mija się z prawdą. W życiu bowiem i w naturze inna jest równowaga świateł i cieni. [...] Gdyby świat, który wzrasta, kwitnie, rozwija się, nie przeważał nad światem umarłym i gnijącym, nie byłoby życia" [tamże, s. 76].

40 Tamże, s. 89.
} 
cywilizacyjnego, kultury pozbawionej nie tylko regulatora z zewnątrz, ale i sił żywotnych.

Obszerny wywód na temat dwóch rodzajów pesymizmu zaprezentuje Sienkiewicz przy okazji recenzowania powieści Alphonse'a Daudeta pod tytułem Numa Roumestan - recenzja pochodzi z grudnia 1881 roku.

Dusza szlachetna - pisze w niej Sienkiewicz - żywo odczuwająca, która na widok złego wpada w rozpacz i targa się i gorzknieje, i szydzi właśnie dlatego, że w jej głębi leży pragnienie dobra, piękności i światła, to objaw szlachetnego pesymizmu, który jeśli padnie na poetę - to poeta mówi jak Słowacki. Ale jest i drugi pesymizm, który widzi jasno zło i podłość, ale godzi się na ich konieczność i gotów wreszcie zrobić z nimi prymirenje - bo jednak trzeba żyćc1.

Ten niebezpieczny mechanizm obojętności i przyzwolenia na zło recenzent dostrzega w nowej powieści Daudeta i... przede wszystkim u Zoli. Dlatego w zakończeniu recenzji pozwala sobie na mocny akcent: "Czytelnik męczy się, ziębnie i wreszcie mimo woli z goryczą pyta, czy tego próchna nie ma także i w duszy autora" ${ }^{42}$. Wracam do wcześniejszego odczytu.

Sienkiewicz, pisząc pod cenzurą, nie może nawet dotknąć problemu braku autonomii kulturowej, ale wiąże się z nią także utrata innych wartości. Jesteśmy w innym położeniu, niż społeczeństwo francuskie, powiada Sienkiewicz. Inne są nasze cele, które w literaturze muszą dawać inne owoce. Pisarz jest zaniepokojony procesem przemiany kulturowej, która polega na pozbyciu się dogmatów stanowiących podstawę tworzenia się wspólnoty ludzkiej - społecznej i narodowej. Utrata autorytetów, sacrum, odczarowanie świata - duchowa spuścizna Wielkiej Rewolucji Francuskiej ${ }^{43}$ - przynoszą współczesnym pokoleniom gorycz i poczucie totalnego zagubienia. Pesymizm nawiedza również dusze polskie i literaturę, ale to inne rozczarowanie. "Jeśli unosi się nad nią smutek, to ten smutek jest raczej tęsknotą za ideałem - nie pesymizmem wyczerpania i zwątpienia... [...] Powieść nasza ma obowiązek

${ }^{41}$ H. Sienkiewicz, Mieszaniny (XVIII), Numa Roumestan, powieść Alfonsa Daudeta, w: tegoż, Dzieła, t. 50, s. 205-206.

42 Tamże, s. 206.

43 Sienkiewiczowski sposób myślenia nasuwa myśl o wpływie Zygmunta Krasińskiego, autora Nie-Boskiej i Irydiona. Bez wątpienia jest to także refleks sposobu myślenia dwóch intelektualistów francuskich, Markiza de Custine'a (Voyage en Russie) oraz Alexisa de Tocqueville'a (De la democratie en Amerique), którzy oddziaływali na Sienkiewicza przed i w trakcie jego podróży amerykańskiej. Na ten temat piszę w artykule Ameryka - dotknięcie Nowego Świata, w: Mity sienkiewiczowskie (w druku). Zob. także: I. Gross, Piętno rewolucji. Custine, Tocqueville, Mickiewicz i wyobraźnia romantyczna, wyd. 2, Warszawa 2000. 
związywać ${ }^{44}$, co jest rozwiązane, być łącznią dusz i według określenia poety, arką przymierza między dawnymi i nowymi laty..." Któż zatem - pyta na koniec Sienkiewicz - chciałby się zrzec "tak wysokiego powołania i iść drogami Zoli?" 45

Czy to pytanie oznacza, że autor Trylogii projektuje siebie samego jako przyszłego przewodnika polskiej duszy?

\section{Sienkiewiczowskie dogmaty}

W stosunku do Sienkiewicza nadużywa się zazwyczaj formuły o „krzepieniu", choć niewątpliwie na długo przed ukończeniem Trylogii (1887), gdzie w dopisku się ona objawi, ma on jakieś poczucie wyjątkowej misji swego narodu - dziś podzielonego, zniewolonego, zdezintegrowanego i poddanego presji zaborców. Ten dogmat, pojawiający się bardzo wcześnie, także tam, gdzie się go nikt nie spodziewa - np. w korespondencji z Wenecji ${ }^{46}$ - to, moim zdaniem, uporczywe trwanie przy idei niepodległości, która, im więcej o niej myślał, tym bardziej wydawała się nierealna, coraz trudniejsza do osiągnięcia. „Wallenrodyzm czy znikczemnienie?” - pisał ironicznie o tych czasach Stanisław Witkiewicz, doświadczywszy po powrocie z zesłania bolesnego zderzenia marzeń z rzeczywistością „plugawej skorupy” ${ }^{47}$. Sienkiewicz Trylogią rzuca $\mathrm{w}$ tę przestrzeń żagiew ${ }^{48}$, udowadniając sobie i innym, że naród bez pamięci o przeszłości jest tylko tłumem bez twarzy. Dlatego jego program literacki nie może czerpać z wzorców Zoli, choć niewątpliwie

${ }^{44}$ H. Sienkiewicz, O naturalizmie. Zwracam uwagę na konotacje użytych epitetów i czasowników: „literatura rozpętana”, „związywać”, „rozwiązywać” i „religare” - z łac. związywać. Nie ma wątpliwości, że Sienkiewicz stosuje tu swoim zwyczajem język ezopowy.

45 Tamże, s. 101.

46 H. Sienkiewicz, Z Wenecji, w: tegoż, Dzieła, t. 44: Listy z podróży i wycieczek. Tu piękna fraza z Janicjusza na zakończenie: „Jać nie boleję, żem sarmackie dziecię...”

47 Zob. fragmenty jego pism, zwłaszcza: Juliusz Kossak (1900), Wallenrodyzm czy znikczemnienie (1904), Matejko (1911) - tu rozdz. 4 z 1908 roku, usunięty przez cenzurę.

48 Tak rozumiał działanie Sienkiewiczowskiej Trylogii w latach 80. Stanisław Witkiewicz. „Z tych kart buchnęła nagle żywiołowa siła plemienna; spod całego samokrytycyzmu, pozytywizmu, pracy organicznej odezwało się silne i czyste echo tych samych drgnień duszy [...]. Społeczeństwo, które przez kilkanaście lat usiłowało wyjść z siebie, które miało tylko «socjalne» dążenia, które goniło za nowymi pojęciami, hasłami, często po prostu za wyrazami z Zachodu, które zdawało się zapominać «na ustach wyrazu», nagle uświadomiło swoją szczególną odrębność, odnalazło w swojej duszy treść wspólną z tymi, którzy poprzez zmienne losy dziejów kładli swoje kości «jako sztandary wojsk zatracone»" [S. Witkiewicz, Juliusz Kossak, w: tegoż, Pisma zebrane, red. Z. Jakubowski, M. Olszaniecka, t. 2: Monografie artystyczne, wstęp i komentarz M. Olszaniecka, cz. 1, s. 7]. 
w uporczywości powrotów do autora Le Débâcle jest coś symptomatycznego. Czyżby magnetyzm wyrazistej osobowości pisarskiej, który nader często skazywał go na rolę jedynego sprawiedliwego?

W latach 80 . Sienkiewicz buduje swój program literacki, przy czym rodzi się on spontanicznie, nie przez teorię, ale raczej w praktyce. Sukces Trylogii zmienia jego sposób myślenia i przyśpiesza ewolucję przekonań. Program literatury naturalistycznej, we Francji znany od lat 60., do Polski dociera z dwóch źródeł: przez sztuki plastyczne i literaturę. Popularyzowany od dawna i chętnie komentowany, co najmniej od czasów Listów o sztuce Godebskiego, na dobre funkcjonujący już w literackiej praktyce, dopiero w latach 80. staje się fundamentem działalności awangardowej grupy literatów i artystów, skupionej wokół warszawskiego „Wędrowca”. Tu piórem Stanisława Witkiewicza polskiego czytelnika uczy się rozumieć nowoczesną sztukę, a Antoni Sygietyński walczy z przeżytkami twórczości tendencyjnej ${ }^{49}$, wskazując nowej literaturze polskiej możliwości odświeżenia swego emploi. Sygietyński jeszcze przed wejściem w struktury „Wędrowca” pisze dla "Ateneum" w latach 1881-1882 obszerne studium na temat nowoczesnej literatury francuskiej. Są tu sylwetki Flauberta, braci Goncourt, Daudeta i Zoli. Gdy czytamy dzisiaj jego esej poświęcony prawodawcy francuskiego naturalizmu bez trudu rozpoznajemy Sienkiewiczowskie frazy i sposób myślenia ${ }^{50}$. Także wysoka ocena Daudeta i uprzywilejowanie w tym gronie pisarstwa Flauberta wydają się sugestią Sienkiewicza z odczytu $O$ naturalizmie ${ }^{51}$. Nie znaczy to, że wszyscy poszli jego tropem i nikogo w Polsce nie stać było na samodzielne oceny. Najbardziej konsekwentnym krytykiem Zoli z pokolenia Sienkiewicza był niewątpliwe Piotr Chmielowski, który już pierwsze przejawy nowej szkoły witał wrogo, potem zaś, w miarę rozwoju naturalizmu, upewniał się coraz bardziej w swoim dlań nieprzejednaniu ${ }^{52}$. Nie należał też do apologetów Zoli Świętochowski, piętnując w nim zamiłowanie do szpetoty życia ${ }^{53}$, co może nieco dziwić, tym bardziej, że właśnie w redagowanej przez niego „Prawdzie” ukazywały się także artykuły pozytywne, np. Daniela Zglińskiego (1883, nr 23) czy w latach 90. - Winiarskiego i Krzywic-

\footnotetext{
49 A. Sygietyński, Nasz ruch powieściowy, „Wędrowiec” 1884, nr 37-39.

50 Takiego zdania jest Janina Kulczycka-Saloni.

51 Pozytywnie wypowiada się Sienkiewicz na temat Salammbô Flauberta, o Madame Bovary wspomina w Listach o Zoli (1893), przy czym Flaubert jest dla niego realistą.

52 P. Chmielowski, Młode siły, „Ateneum” 1881, t. 1, s. 13. Tenże, Olbrachtowi rycerze, „Biblioteka Warszawska", 1890, t. 2, z. 2, s. 292.

53 Zob. A. Świętochowski, Liberum veto (poeci i pisarze jako reformatorowie społeczni), „Prawda” $1895, \mathrm{nr} 47$.
} 
kiego ${ }^{54}$. Zwłaszcza ten ostatni Zoli przyjrzał się z uważnością, stwierdzając, iż przy całej niechęci do społeczeństwa współczesnego, trywialnego i zmaterializowanego, Zola pozostaje analitykiem zmiany społecznej, mało subtelnym, gdy idzie o duszę ludzką, trafnym tam, gdzie mówi się o masach, organizmie społecznym czy instytucjach nowoczesnego życia.

Czy na tym tle Sienkiewicz prezentuje się jako nieprzejednany przeciwnik Zoli? Otóż nie. Nawet w ostatnim poświęconym mu tekście krytycznym, artykule Listy o Zoli (1893), francuski pisarz jest w jego ujęciu przykładem kogoś, kto, mając wszystkie przymioty artysty, zmarnował swój talent dla jałowej doktryny. Sienkiewicz wie, że obcuje z geniuszem, kiedy czyta La Débâcle lub Germinal ${ }^{55}$. Pisze o Zoli:

Talent wielki, siła powolna, ale wielka i cierpliwa, obiektywizm, jeśli mowa o uczuciu, zadziwiający, bo równy zupełnej prawie obojętności, dar widzenia zbiorowej duszy ludzkiej i rzeczowej tak wyjątkowy, że zbliżający tego naturalistycznego pisarza do mistyków - czynią z niego postać niepowszednią i bardzo oryginalną ${ }^{56}$.

Polak nie umie jednak zachwycić się ostatnim ogniwem cyklu (powieść Doktor Pascal), w którym Zola pogrążył się w doktrynerstwie, tworząc postacie papierowe i wypchane teoriami. Nie umie mu zapomnieć powieści La Terre, w której człowiek niewiele różni się od swego inwentarza, a wieś symbolizuje jedynie występek i błoto. Na szczęście, stwierdza w końcu - czas Zoli przemija.

W tym ostatnim tekście Sienkiewicz mówi o niepokoju drążącym Francję współczesną. Nie wiem, czy dokładnie idzie mu o reakcję na naturalizm, która narasta od końca lat 70. i osiąga apogeum w 80., a jej skrajnym wyrazem był Manifest Pięciu ${ }^{57}$, ale pisarz znakomicie wychwytuje pewne zapowiedzi zmiany. Na razie - pisze - widać poszukiwanie i niepokój, przede wszystkim $\mathrm{w}$ młodym pokoleniu.

Patrz na ostatnie książki Bourgetów, Rodów, Barresów, Desjardinów, na poezje Rimbauda, Verlaine'a, Heredii, Malarmé'go, a choćby Maeterlincka i jego szkoły. Co w nich jest? Poszukiwanie nowej treści i nowych form, [...] niepew-

\footnotetext{
54 K.R. Żywicki [L. Krzywicki], Psycholog mas ludzkich, „Prawda” 1898, nr 32-34.

55 „Ogrom socjalizmu i ogrom wojny zgniotły po prostu Zolę z całym jego aparatem umysłowym. Jego doktryny zmalały wobec takich rozmiarów i zaledwie je słychać w szumie powodzi zalewającej kopalnię i przy huku dział pruskich. Został tylko talent. Toteż i w tej, i w tamtej powieści są prawdziwe dantejskie karty” [H. Sienkiewicz, Listy o Zoli („Le Docteur Pascal”), w: tegoż, Dzieła, t. 45: Szkice literackie, t. 1, s. 138].

56 Tamże, s. 131.

57 Manifeste de Cinq, protestacyjny list otwarty młodych pisarzy do Emila Zoli z 18 sierpnia 1887 roku, po publikacji La Terre.
} 
ność, gdzie się zwrócić i gdzie szukać ratunku; czy w mistycyzmie, czy w wierze, czy w obowiązkach poza wiarą, czy w patriotyzmie, czy w ludzkości? Przede wszystkim jednak widać niepokój ogromny ${ }^{58}$.

Zaraz też dodaje, że wszyscy oni z braku talentu brną w dziwactwach zwanych symbolizmem czy impresjonizmem. Tak, nie ma wątpliwości: Sienkiewicz ich nie rozumie. Sienkiewicz - klasyk, zwolennik estetyki idealistycznej, który mógłby powtórzyć za swym nauczycielem akademickim, Henrykiem Struve, że sztuka to przestrzeń urzeczywistnienia się ideałów. Ale z drugiej strony - nie można powiedzieć, że nie próbuje ich jakoś zrozumieć. Co więcej, jego twórczość także stać się może źródłem paradoksu. On sam, choć jest innego zdania, z powodzeniem wprowadzał technikę deskrypcji naturalistycznej - Szkice węglem, Jamioł ${ }^{59}$ czy Bez dogmatu - to przykłady wręcz modelowe. Jego intuicyjny impresjonizm to wręcz znak rozpoznawczy epickich malowideł, choćby Trylogii ${ }^{60}$. O sile Sienkiewiczowskiego obrazu, który aż „przygniata myśl” pisał Andrzej Bobkowski, podkreślając, że pisarz jest wynalazcą technik, jakimi dzisiaj powszechnie posługuje się kino - stereofonii, cineramy i technicoloru ${ }^{61}$.

Kto zatem ma tu rację? Sienkiewicz, Zola, a może my, komentatorzy dzieł wielkich mistrzów? Podczas konferencji kieleckiej (wrzesień 2016) w wystąpieniu Marka Tomaszewskiego (INALCO, Paryż) ${ }^{62}$ usłyszałam, że wszystkie opinie Sienkiewicza na temat Zoli powiązać należy z tym, iż Francja po Sedanie przeżywała niesłychanie trudny czas, a najostrzejszym przejawem tego kryzysu stała się sprawa Dreyfusa, pilnie obserwowana również przez pisarzy polskich, np. Żeromskiego, Reymonta, a na pewno Sienkiewicza, który zresztą w korespondencji prywatnej kilkakrotnie się na ten temat wypowiadał ${ }^{63}$. Z pewnością jest tu coś na rzeczy, choć sprawa Dreyfusa to

\footnotetext{
58 H. Sienkiewicz, Listy o Zoli, s. 130.

59 W korespondencji prywatnej ze S. Witkiewiczem Sienkiewicz pisze o granicy, której w Jamiole nie przekroczył. List z 13 stycznia 1881 roku. Zob. H. Sienkiewicz, Listy, t. 5, cz. 2.

60 Na temat impresjonizmu sienkiewiczowskiego zob. B. Mazan, „Impresjonizm” Trylogii, Łódź 1993.

61 Wypowiedź Andrzeja Bobkowskiego pojawiła się w ankiecie „Wiadomości” londyńskich w 1961 roku. Zob. moją książkę Zabijanie klasyków. Studia i eseje, Białystok 2015, s. 195-196.

62 M. Tomaszewski, Kilka uwag na marginesie recepcji "Quo vadis" Henryka Sienkiewicza we Francji. Referat wygłoszony na konferencji: Sienkiewicz: tekst, lektura i społeczna praxis, Kielce (15-17 września, 2016).

63 Tu ważna wypowiedź w liście do Jadwigi Janczewskiej: „Czytałem Paris Zoli. - Co do jego sprawy, wiem rzeczy zakulisowe. Naturalnie, że nie Dreyfus winien, i wszyscy tu o tym wiedzą, ale mówią, że nie można było inaczej. Zaczyna się jednak reakcja za Zolą". H. Sienkiewicz, Listy, t. 2, cz. 3, s. 252 (list z 16 marca 1898).
} 
wydarzenie późniejsze niż Sienkiewiczowskie wystąpienia, będące wynikiem obserwacji rozwoju literatury w Europie i zainteresowania polityką.

Żeby dopełnić te rozważania, przywołam jeszcze jedną opinię. Jest to artykuł Macieja Żurowskiego Sienkiewicz i literatura francuska z 1968 roku $^{64}$. Po pierwsze, przypomina on, że artykuły Sienkiewicza na temat Zoli i naturalizmu pojawiają się $\mathrm{w}$ okresie wyznaczonym, $\mathrm{z}$ jednej strony, przez apogeum kierunku - to jest wydanie Nany, książki-manifestu Powieść eksperymentalna i Wieczorów medańskich (1880), z drugiej - jego schyłkiem, czyli publikacją Doktora Pascala (1893), czemu u Sienkiewicza z kolei odpowiadają wydarzenia tak różne, jak pisanie i edycja Trylogii (1883-1887), a z drugiej strony - wydanie Bez dogmatu (1890) i praca nad Rodzinq Połanieckich. Wypowiedzi pisarza na tematy literackie są więc absolutnie podstawowe dla oceny jego świadomości twórczej. Wymagają też interpretacji dużo głębszej, niż gdyby były tylko recenzencką połajanką. Koniecznie też trzeba w tym miejscu przypomnieć, że jeśli na początku Sienkiewicz widzi w naturalizmie tylko nieco ostrzejszy realizm i rzecz sprowadza do modnej brutalnej estetyki, to w ostatnich wypowiedziach rozpoznaje $\mathrm{w}$ nim pewną koncepcję antropologiczną, $\mathrm{i}$ to dopiero go przeraża.

Po drugie - powiada Żurowski, trudno przyjąć obiegową formułę, że

niedawny pozytywista, dokonujący właśnie zwrotu w stronę konserwatystów, potępia w słynnym odczycie O naturalizmie w powieści (1880) Zolę i jego szkołę dlatego, że materialistyczne i przyrodnicze elementy naturalizmu oraz jego demaskatorska ostrość kazałaby mu widzieć rzeczywistość w sposób podważający jego nową postawę klasową ${ }^{65}$.

Taki pogląd, jak mi się wydaje, mógł jeszcze funkcjonować w PRL-u. Dziś trudno to przyjąć, a jeszcze trudniej utrzymać w mocy, skoro Sienkiewicz, nie odchodząc zresztą od poziomu argumentów powszechnie stosowanych w epoce, dla której powieść naturalistyczna była zbyt szokująca, potrafił, różniąc się w tym od innych, zachować w swoich sądach rozsądek i umiar. Pisze Żurowski dalej tak:

Sienkiewicz [...] nie tylko nie gani Zoli za idee wywrotowe, lecz przeciwnie, chwali typy i dzieła, które powinien był piętnować ze swojego stanowiska politycznego. Potrafi też, co było może najtrudniejsze, zdobyć się na pełne zrozumienie tych rysów artyzmu Zoli, które osobiście były mu jak najbardziej obce ${ }^{66}$.

64 M. Żurowski, Sienkiewicz i literatura francuska. Sienkiewicz dzisiaj. Studia i szkice, wyb. i oprac. T. Jodełka-Burzecki, red. J. Z. Jakubowski, Warszawa 1968.

65 Tamże, s. 121.

66 Tamże, s. 129. 
Potwierdzam. Sienkiewiczowi nie przeszkadzają polityczne czy społeczne poglądy Zoli, ale zaniedbania artystyczne, fanatyzm przylepionej do jego pisarstwa teorii. Nawet jeśli nie podziela jego wyborów estetycznych, potrafi wznieść się ponad swoje preferencje i docenić nowatorstwo w dziedzinie deskrypcji. „Takich pochwał za swoje opisy - dodaje Żurowski - Zola nie zbierał jeszcze we Francji [...]" ${ }^{\prime 67}$. [podkr. - J. Sz.] Już choćby z tego względu - podkreśla - „Sienkiewicz krytyk zasłużył na uważniejsze traktowanie" 68 .

Od siebie dodam tylko tyle: Sienkiewicz jest zafascynowany Zolą, bo jego pisarstwo - namiętne, polityczne, ryzykowne i wolne - jest awersem roli, w którą po krótkim okresie młodzieńczego buntu sam nolens volens - po triumfie Trylogii ${ }^{69}$ - wchodził.

\section{Towards Zola}

\section{Summary}

The article re-evaluates the dominating view of the clearly negative relationship between two writers, Sienkiewicz and Zola. It presents the implications of Sienkiewicz's 1878 visit to France, and further, it reconstructs his opinions that chronologically coincided with Zola's greatest popularity. The text provides an analysis of Sienkiwicz's remarks on Zola's style, and it proves further that his naturalism did, in fact, help Sienkiewicz develop his own literary technique. Finally, the Polish author's long-term interest in Zola's writing certainly demonstrates his fascination with this famous literary persona.

Keywords: Henryk Sienkiewicz, Émile Zola, relationship between writers, naturalism

\footnotetext{
67 Tamże, s. .127.
}

68 Tamże, s. 128.

69 Problem z recepcją Trylogii, a właściwie jej „symbolicznym przejęciem” przez jedną ze stron politycznej agory najtrafniej uchwycił Z. Najder: „Złośliwy los sprawił, że najświetniejsze dzieło Sienkiewicza stało się przyczyną jego tragedii artystycznej i ideowej. Trylogia nie została zrozumiana i doceniona przez lewe skrzydło polskiej inteligencji. Natomiast krakowska konserwa uczyniła z niej coś w rodzaju biblii politycznej i artystycznej - z wielką szkodą dla powieści, ponieważ nie obeszło się bez zniekształceń i fałszerstw w interpretacji. [...] Na wpół świadomie pisarz bronił się przed tą aneksją. Nurtowało go silne poczucie bezsensu otaczającej go rzeczywistości, wstręt do snobizmu, obłudy, płaskiego materializmu połączonego z bigoterią" [Z. Najder, O „Listach z Afryki” Henryka Sienkiewicza, „Pamiętnik Literacki” 1956, z. 4, s. 336]. 